\title{
R\&D of Long-Term Life Support System by Using Electrochemically Activated Biofilm Reactor of Aquatic Animals for Space Examinations
}

\author{
Kouichi Ichikawa ${ }^{1}$, Hiroshi K. Nakamura ${ }^{1}$, Naoki Ogawa ${ }^{1}$, Toru Sakimura ${ }^{2}$ and Masao Kuroda ${ }^{3}$ \\ ${ }^{1}$ Takasago Research \&Development Center, Mitsubishi Heavy Industries, Ltd., 2-1-1 Shinhama, Arai-cho, \\ Takasago, Hyogo 676-8686, Japan \\ ${ }^{2}$ Kobe Shipyard \& Machinery Works, Mitsubishi Heavy Industries, Ltd., 1-1-1 Wadasaki-cho, Hyogo-ku, Kobe, \\ Hyogo 605-8585, Japan \\ ${ }^{3}$ Department of Civil Engineering, Gunma University, 1-5-1 Tenjin-cho Kiryu, Gunma 376, Japan
}

\begin{abstract}
We have developed the long-term life support system that enables the experiment of aquatic animals breeding for 90 days or more for the future experiments in orbit. In order to enable long-term breeding of wide aquatic animals, it is necessary to remove nitrate produced by biological nitrification. Then, we examined a denitrification method to use an electrochemical reaction of biofilm-electrode reactor. In this research, we have not kept the aquatic animals actually but imitated breeding of five goldfish. The ammonia of about $250 \mathrm{ppm}$ was added in breeding water through 90 days. As a result, neither ammonia nor nitrite accumulated $0.1 \mathrm{ppm}$ and nitrate could be suppressed to about $10 \mathrm{ppm}$.
\end{abstract}

Key words; electrochemical denitrification, long-term life support system, biofilm, biofilm-electrode reactor

\section{Introduction}

We have developed the long-term life support system that enables the experiment of aquatic animals breeding for 90 days or more for the future experiments in orbit. As for breeding of aquatic animals under the space environment, the effective use of limited water resource becomes a problem (Endo et al., 1999). It is thought that breeding aquatic animals without exchanging the water in the closed system is important at the point of saving the water resource and researching the material circulation under closed environment (Endo et al., 1999). Many experiments with various aquatic animals have been performed in the space shuttle (Ijiri, 1995; Nagaoka et al., 1998) and those aquatic animals have been bred in sealed containers with a limited amount of water under microgravity. The development of basic technology for the life support system is indispensable for biological research in space (Nakamura et al., 1996a; 1996b; Nakamura et al., 1998a; 1998b).

Both the stable removals of ammonia and nitrite and countermeasures against decrease of $\mathrm{pH}$ in the breeding water are necessary for aquatic animals breeding (Nakamura et al., 1996a). Biological nitrification is a very effective way to resolve this problem (Nakamura et al., 1996b). Biological nitrification is the reaction of ammonia and/or nitrite oxidizing to nitrate by two kinds of nitrifying bacteria. In earlier studies, it is not necessary to remove nitrate promptly because of the low toxicity. However, in order to enable long-term breeding of wide aquatic animals,

Original Paper

Received: December 15, 1999.

Accepted: December 30, 1999.

Address for correspondence: Kouichi Ichikawa ichikawa.wr@trdc.mhi.co.jp it is necessary to remove nitrate in the water, because the accumulation of nitrate causes the $\mathrm{pH}$ to decrease.

Biological denitrification, which is one of the effective ways to remove the nitrate in the water by reduction of nitrate or nitrite to nitrogen gas, required organic compounds as an electron donor (Knowles, 1982). The availability of electrons in organic compounds is one of the most important factors controlling the activity of biological denitrification. Methanol is used as organic compounds in general waste water treatment (Suzuki et al., 1993). However, it cannot be used for space experiments, because it is combustible and toxic for aquatic animals. We applied the method of the denitrification used glucose as organic compounds, and succeeded in breeding on goldfish (fresh-water fish) and oyster toadfish (marine fish) for 90 days (Nakamura et al., 1998a; 1998b).

In this research, we adopted the electrochemical reaction of biofilm-electrode reactor (Sakakibara et al., 1993-1997) instead of adding organic compounds for biological denitrification, and purified the breeding water. In this paper we described the results of the experiment of purifying breeding water with the life support system supplemented the biofilm-electrode reactor.

\section{Material and method}

\section{Experiment apparatus}

The flowsheet of the experiment apparatus is shown in Figure 1 and Table 1 shows the specification. The total volume of breeding water was $3.2 \mathrm{~L}$ and flow rate was assumed to be $1 \mathrm{~L} / \mathrm{min}$. The gas exchange (oxygen/carbon dioxide) in the breeding water was with the pump oxygenator (Terumo Capiox II 08). The breeding water temperature was controlled $23{ }^{\circ} \mathrm{C}$. We loaded $1.8 \mathrm{mg} / \mathrm{L}$ of ammonia to imitate five goldfish (body length about $3 \mathrm{~cm}$, body weight about $1.5 \mathrm{~g}$ ) breeding, and fed $0.2 \mathrm{~g}$ of food 
Table 1 Specification of the Experimental Unit

\begin{tabular}{ll}
\hline Water & distilled water \\
Water volume & $3.2 \mathrm{~L}$ \\
Operation temperature & $23^{\circ} \mathrm{C}$ \\
Circulation rate & $1 \mathrm{~L} / \mathrm{min}$ \\
Feeding & $0.2 \mathrm{~g} /$ day \\
Nitrification tank volume & $400 \mathrm{ml}$ (glass beads) \\
Denitrification tank volume & $1000 \mathrm{ml}$ (carbon pellet) \\
Experimental period & 90 days \\
\hline
\end{tabular}

(Kyorin Co., Ltd., Babygold) everyday. The water purification system consists of combined biological method (nitrification and denitrification). $400 \mathrm{ml}$ of nitrifying bacteria adhesion glass beads carrier (Schott, Siporax) was filled in the nitrification tank and $1000 \mathrm{ml}$ of denitrifying bacteria adhesion carbon pellets (Koujundokagakukenkyujo Co., Ltd.) was in the denitrification tank. The nitrifying bacteria we used here are the same strains in the Vestibular Function Experiment Unit (VFEU) at the NEUROLAB and STS-95 missions (Nagaoka et al., 1998). We used two kind of strains, one was Nitrosomonas sp. MK8 (FERM P-12555) and another was Nitrobacter sp. IM203 (FERM P-12556) as nitrifying bacteria (Nakamura et al., 1991). Electric current value running through the electrodes in the denitrification tank was controlled to be $5 \mathrm{~mA}$, and retention time of denitrification tank was assumed 6 hours.

\section{Water analysis}

The concentrations of ammonium ( $\mathrm{NH}_{4}-\mathrm{N}$, indophenol blue photometry), nitrite ( $\mathrm{NO}_{2}-\mathrm{N}$, Griess-Romijn Method), nitrate $\left(\mathrm{NO}_{3}-\mathrm{N}\right.$, brucine sulfanilic acid method) and $\mathrm{pH}(\mathrm{pH}$ electrode, COS) were measured.

\section{Results}

The relation between electric current and denitrification rate is shown in Figure 2. We defined a denitrification rate

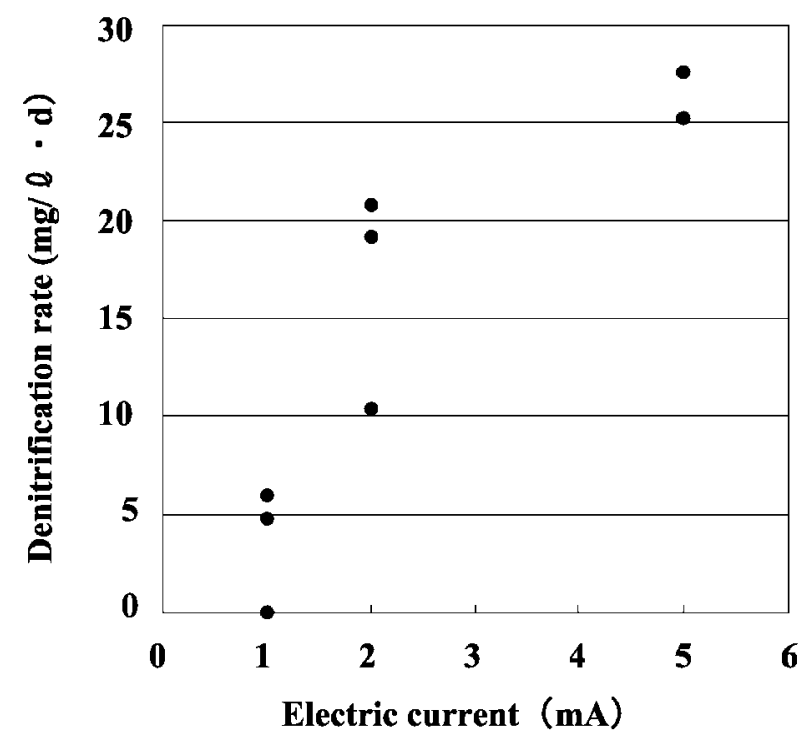

Fig.2 Electric current-dependence of denitrification rate

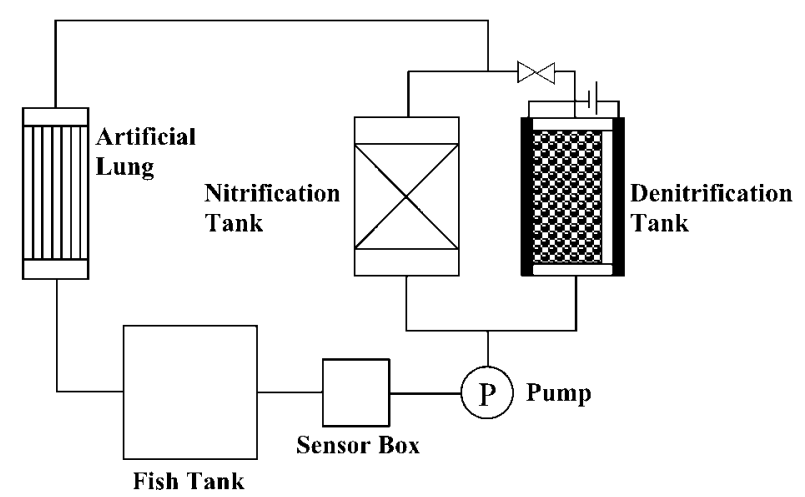

Fig.1 Diagram of experimental apparatus.

as a nitrate decrease of one liter of denitrification tank water at a day. The denitrification rate was a linear function of electric current in the range of 1-5mA. The excretion of five goldfish was calculated about $5.8 \mathrm{mg} / \mathrm{d}$ of ammonia and about $5 \mathrm{mg}$ of ammonia was included in $0.2 \mathrm{~g}$ of fish food "Babygold". Thus, when five goldfish are bred in this system, about $11 \mathrm{mg}$ of ammonia is accumulated in breeding water everyday. As the denitrification tank keeps $500 \mathrm{ml}$ of water, denitrification rate required more than 22 $\mathrm{mg} / \mathrm{L} / \mathrm{d}$ to prevent nitrate accumulation. As was clear from Fig. 2, it was found that the required denitrification rate $(22 \mathrm{mg} / \mathrm{L} / \mathrm{d})$ was obtained in running at $2 \mathrm{~mA}$ or more. On the other hand, it was $4 \mathrm{~mA}$ that theoretical electric current value to obtain the required rate above. We decided the electric current value at the long-term examination $5 \mathrm{~mA}$, because of processing performance change and the theoretical electric current value.

Figure 3 shows time course of $\mathrm{NH}_{4}-\mathrm{N}, \mathrm{NO}_{2}-\mathrm{N}$ and $\mathrm{NO}_{3}-$ $\mathrm{N}$ concentrations and $\mathrm{pH}$ of breeding water on the longterm examination. Ammonia and nitrite were continuously $1 \mathrm{ppm}$ or less through the examination period. Nitrate remains little until the 30th day and has increased up to about $10 \mathrm{ppm}$ after that. However, after the day 30, nitrate concentration became constant about $10 \mathrm{ppm}$ and $\mathrm{pH}$

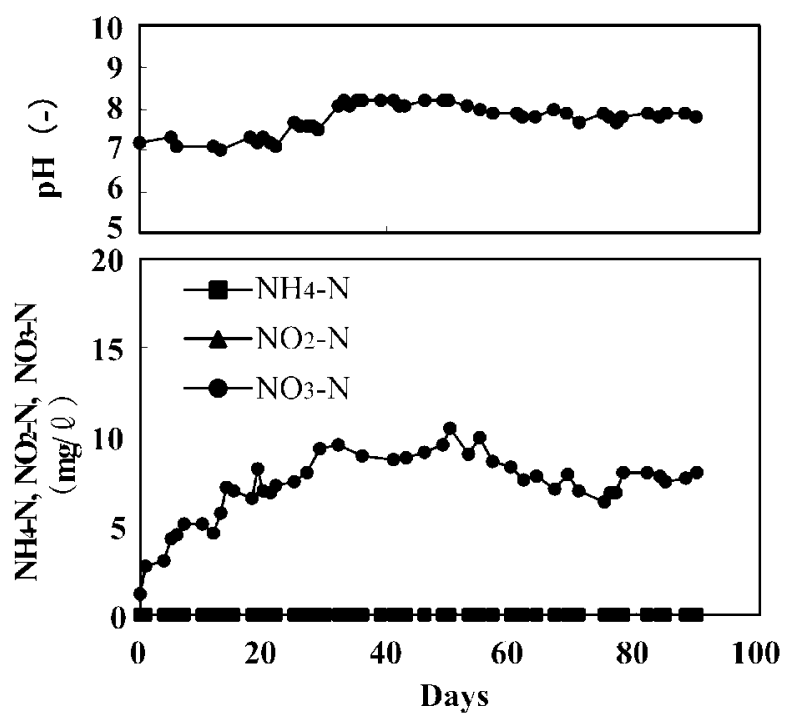

Fig.3 Time course of water quality 
indicated stable about 8 .

\section{Discussion}

Since 1992, we have achieved five experiments with aquatic animals on space shuttle missions, which were named FMPT, SL-J, IML-2, NEUROLAB and STS-95. These previous experimental periods were short term, up to 3 weeks. The purification method in these experimental units was chemical adsorption with zeolite or biological nitrification. However, more long experimental period will be required for the future experiments in orbit such as those at the International Space Station (ISS). Aquatic animals can be expected to be kept for 90 days or more in space. Though nitrate was not removed at the shuttle experiments, it will be necessary to remove nitrate in the breeding water at the ISS experiments. It is because high accumulation of nitrate caused the toxicity to increase and the $\mathrm{pH}$ to decrease.

Biological denitrification is one of nitrate removal methods. We had already applied this method for life support system and succeeded in breeding on goldfish and oyster toadfish for at least 90 days (Nakamura et al., 1998a; 1998b). However, this system required excess carbon source (i.e. glucose), and that we added excess glucose in our previous experiment (Nakamura et al., 1998a; 1998b). The result was that carbon compounds in breeding water increased and various microorganisms grew to consume the carbon compounds in breeding water. Therefore, we desired new water purification method by which nitrate was removed and no pollution of breeding water occurred besides.

In this research, we used the biofilm-electrode reactor for denitrification and obtained satisfactory results, that is, no accumulation of nitrate and $\mathrm{pH}$ maintenance of comfortable range for aquatic animals as shown in fig 3 . These results demonstrated the effectiveness of using life support system supplemented the biofilm-electrode reactor.

The purpose of this study was to obtain running data of water quality, when constant ammonia loading was given by addition of chemicals instead of breeding aquatic animals actually. The performance under the condition of irregular loading will be obtained by breeding aquatic animals actually in the future work. Moreover, we are also scheduled to examine processing of the bubbles of nitrogen gas generated by denitrification reaction.

\section{References}

Endo, M., Takeuchi, T., Yoshizaki, G., Toyobe, M., Kanki, R., Ohmori K., Oguchi M. and Kibe, S. (1999) Studies on Development of Closed Ecological Circulating Aquaculture System (CERAS) IV. A Long-term Feeding Experiment with Oreochromis niloticus in the Fish-rearing Closed Tank. CELSS, 11, 17-24.

Ijiri, K. (1995) Fish mating experiment in space-What it aimed at and how it was prepared. Biol. Sci. Space, 9, 3-16.

Knowles, R. (1982) Denitrification. Microbiological Reviews, 46,
43-70.

Nagaoka, S., Matsubara, S., Kato, M., Uemura, M., Uchida, S. and Ogawa, N. (1998) Water quality in VFEU life support system during the Neurolab flight. Biol. Sci. Space, 12, 216217.

Nakamura, H. K., Harada, H., Ochiai, T. and Takaoki, M. (1996a) $\mathrm{R} \& \mathrm{D}$ of long-term life support system of aquatic animals for space examinations. Pt. I. Biol. Sci. Space, 10, 152-153.

Nakamura, H. K., Harada, H., Ochiai, T. and Takaoki, M. (1996b) R\&D of long-term life support system of aquatic animals for space examinations. Pt. II. Biol. Sci. Space, 10, 154-155.

Nakamura, H. K., Ogawa, N., Uchida, S., Ochiai, T. and Takaoki, M. (1998a) Water Purification System by Using Biofilter for Long-Term Life Support of Aquatic Animals for International Space Station. MHI technical report, 35, 346349 .

Nakamura, H. K., Ogawa, N., Uchida, S., Ochiai, T. and Takaoki, M. (1998b) Water purification system by using the biofilter for long-term experiment equipment with aquatic animals for the space station, Life Support \& Biosphere Sci., 5, 353-356

Nakamura, K. (1990) Removal of Nitrogen and Phosphate in the Waste Water. In:Microbiologic Technical Handbook ed. Suzuki, T., Asakurashoten (Tokyo), pp578.

Nakamura, T., Ogawa, N., Tabata, M. and Kamiyoshi, H. (1991) Effect of Organic Compounds on Growth of Nitrosomonas and the Activity of Nitrifying Bacteria at Cold Temperature. MHI technical report, 28, 569-571.

Sakakibara, Y. and Kuroda, M. (1993) Electric Prompting and Control of Denitrification. Biotechnology and Bioengineering, 42, 535-537.

Sakakibara, Y., Flora, J. R. V., Suidan, T. and Kuroda, M. (1994) Modeling of electrochemically-activated denitrifying biofilms. Wat. Res, 28, 1077-1086.

Sakakibara, Y., Araki, K., Tanaka, T., Watanabe, T. and Kuroda, M. (1994) Denitrification and neutralization with an electrochemical and biological reactor. Wat. Sci. Tech., 30, 151155.

Sakakibara, Y., Araki, K., Watanabe, T. and Kuroda, M. (1997) The denitrification and neutralization performance of an electrochemically activated biofilm reactor used to treat nitratecontaminated groundwater. Wat. Sci. Tech., 36, 61-68. 